\title{
The Concept of Fitrâh In The Qur'ân And The Implications With Children's Education
}

\author{
1Sudrajat, 2Sun Agustine Prolawati Dwipoyono \\ 1Universitas Muhammadiyah Cirebon \\ ${ }^{2}$ SMKN 1 Gunung Jati Kabupaten Cirebon \\ E-mail: ${ }^{1}$ sudrajat@umc.ac.id, ${ }^{2}$ sunagustine@yahoo.co.id,
}

\begin{abstract}
The concept of fitrâh as original goodness connotes a passive acceptance of good and right actions and an active and innate tendency to know Allah and submit to Him. Religion functions as a human moral control. Because religion commands humans always to be aware and able to control themselves Q.S al-Rum: 30, Fitrah sees humans as having selfpotential. This potential is the power or strength to accept the religion of monotheism. Therefore, the environment and education have a strategic role in developing human nature. A well-educated fitrah will make itself a nation that loves peace, is inclusive and continues to compete (continuous improvement). The implication of nature on children's education aims to develop the potential of students to become human beings who have faith and piety, have a noble character, are healthy, knowledgeable, capable, creative, independent, and become responsible citizens.
\end{abstract}

Keywords: Fitrâh, al-Qur'ân, Education, Children

\begin{abstract}
Abstrak: Konsep fitrâh sebagai kebaikan asal, tidak hanya berkonotasi penerimaan pasif terhadap yang baik dan benar tindakan, tetapi kecenderungan aktif dan bawaan alami kecenderungan untuk mengenal Allah serta tunduk kepada-Nya. Agama berfungsi sebagai kontrol moral manusia. Sebab agama menyuruh manusia untuk selalu dalam keadaan sadar dan dapat menguasai diri Q.S al-Rum: 30. Fitrâh memandang manusia memiliki potensi diri. Potensi tersebut adalah daya atau kekuatan untuk menerima agama atau Tauhid. Oleh karena itu, lingkungan dan pendidikan memiliki peran strategis dalam mengembangkan fitrâh manusia. Fitrâh yang terdidik dengan baik akan menjadikan dirinya sebagai generasi bangsa yang cinta damai, inklusif dan terus bersaing (continous improvement). Implikasi fitrâh terhadap pendidikan Anak bertujuan mengembangkan potensi peserta didik agar menjadi manusia yang beriman dan bertakwa, berakhlak mulia, sehat, berilmu, cakap, kreatif, mandiri, dan menjadi warga negara yang bertanggung jawab.
\end{abstract}

Kata Kunci: Fitrâh, al-Qur'ân, Pendidikan, Anak

\section{INTRODUCTION}

Muslims are currently experiencing various problems, from anxiety about being left behind in all fields to authoritarianism and a literal understanding of the holy book. Some consider being contrary to universal values that believe to be related to justice upholding human dignity and equality, gender. ${ }^{1}$

1 Sheyla Niclatus Sovia, “Interpretasi Kontekstual (Studi Pemikiran Hermeneutik al-Qur'ân Abdullah Saeed)”, Jurnal Studi Islam dan Sosial Dialogia Vol. 13 No. 1 (Juni, 2015), 52

Al-Manar : Jurnal Komunikasi dan Pendidikan Islam - Volume 10, Nomor 2, Desember 2021 
Allah on this earth created humans because of their duties and responsibilities as caliphs. Humans are endowed with two elements, physical and spiritual. In this spiritual and physical element, God gave a set of basic abilities or innate. In the view of Islam, this basic ability or innate is fitrâh. Fitrâh is also often interpreted as holy, pure, even natural or natural.

The word fitrâh contains some meanings from the point of view of the scholars. Muslim experts give several opinions regarding the nature of the verse; among others, it is said that fitrâh is the religion of Islam and has a tendency to the religion of monotheism as a tract of the Apostles. In contrast, others say that fitrâh can be interpreted with basic potential cultivated according to interests. ${ }^{2}$

Abdurrahman clarifies the interpretation of experts on fitrâh into three: the first means Islam, the second means monotheism or at least identical with monotheism, and the third means the form given to humans at the time of its creation. Therefore, humans must direct that faith to faith in Allah. ${ }^{3}$

Several verses have a nature editorial based on the search, including Surah Yasin: 22; Surah al-Shura: 11; Surah al-An'am: 79; Ar-Rum: 30. The verses above are some of the many verses that contain the fitrâh. These verses are interpreted in different meanings with different understandings, and the understanding of nature in these verses often invites debate to find meaning and understand it appropriately.

Allah created creatures based on their nature. Fitrah is the potential and creativity that can grow and develop beyond their physical abilities. If it did not seek to grow and develop, human potential and creativity given by God would surely be less meaningful for human life. Therefore, human potential and creativity must pursue. Fitrah can understand from entomological, theological, and even the meaning of context in understanding a verse (nasabi).

As creatures of God's creation, humans are obliged to fulfil their duties and responsibilities as caliphs on earth. Humans give gifts of two elements, physical and spiritual. On this spiritual and physical element, God gave a set of basic abilities or innate. This essential ability or innate ability in Islam is known as fitrah. The word fitrah is interpreting as holy, pure, even natural or natural.

The word fitrah based on the perspective of scholars has several meanings, including; First, fitrah has a tendency to the religion of monotheism as the message of the Apostles. Second, the opinion that fitrah can interpret as an essential potential that can develop according to interests.

2 Dawam Raharjo, Ensiklopedi al-Qur'an: Tafsir Sosial Berdasarkan Konsep Konsep Kunci, (Jakarta: Paramadina, 2002), 39.

${ }^{3}$ Abdurrahman Saleh Abdullah, Teori-Teori Pendidikan Berdasarkan Al-Qur'ân, terj. HM Arifin dan Zainuddin (Jakarta: Bhineka Cipta, 1990), 59. 
The study of the concept of fitrâh is essential because the author realizes that a contemporary humanitarian situation (especially in the West, and to some extent has spread to the East and third world countries) related to the discussion of human nature (origin of occurrence, sanctity) has been polluted by disequilibrium. Quite spiritually. It happens when the arrival of globalization also brings the offering of norms and values to view life.

\section{RESEARCH METHODS}

The method used in this study is a descriptive approach that departs from the type of qualitative study. Phenomena that occur in the field become the primary reference to why the problems in this paper are essential to raise and discuss. When religious adherents no longer find comfort and fall into a deviant territory, this is a sign of academic anxiety.

This study uses a subjective hermeneutical method developed by Hans-Georg Gadamer and Jacques Derrida. ${ }^{4}$ The point of view of subjective hermeneutics, hermeneutics does not only look for the objective meaning understood by the author as imagined by the objective hermeneutic model but also includes what describe itself. The emphasis of the subjective hermeneutical method is not on the author's original idea but on the content of the text itself. ${ }^{5}$

Several studies that have been carrying out shortly support and reinforce factors for the author to state that deviant behaviour is becoming increasingly massive. Borrowing the insider and outsider methods developed by Kim Knott ${ }^{6}$, this paper tries to look at the deviations in the behaviour of religious people through the eyes of the researchers themselves and also look at the results of the analysis of outsiders whose positions are outside of a particular religion.

Khaled Abou El Fadl's ${ }^{7}$ hermeneutic approach can also help with proper data visualization. According to Abu El Faddle, reading texts and information must pay attention to 5 special requirements: honesty, diligence, completeness, rationality and self-control. In addition, reading the text requires negotiation between the text, the writer, and the reader in the sense that they must pay attention to the socio-cultural conditions and the writer's environment and the culture that influences it.

This study is normative. This study is still needed, as said by Baharuddin ${ }^{8}$, because, after all, studies on Islam cannot be separated from normative studies of

\footnotetext{
${ }^{4}$ Fazlur Rahman, Islam dan Modernitas, terj. Ahsin Muhammad, (Bandung: Pustaka, 1985), 13.

${ }^{5}$ K. Bertens, Filsafat Barat Abad XX, I, (Jakarta, Gramedia, 1981), 231.

6 Knott, K. (2005). Insider/outsider perspectives. The Routledge companion to the study of religion, 243-258., 134

7 Khaled M. Abou El Fadl, Speaking in The God's Name: Islamic Law, Authority, and Women (Oxford: Oneworld Publications, 2003), 58

${ }^{8}$ Baharuddin, Aktualisasi Psikologi Islami, cet. II, (Yogyakarta: Pustaka Pelajar, 2011), 14.
} 
Islamic teachings. The problem becomes different if only normative studies are considered necessary. Scientific studies in Islam should be able to combine and present the normativity and historicity of human religiosity. The language of the "market" grounded the concept of the Qur'an through scientific interpretation and study. Instructions in various ways, both in the form of thinking, acting and being creative. ${ }^{9}$

\section{DISCUSSION}

\section{A. THE CONCEPT OF FITRÂH IN THE QUR'AN}

The word fitrah is the isim mașdar form of the word fi'lah such as the pronunciation of al-jilsah (sitting state). The word fi'lah from fatara-yafțuru means al-syaqq (split)10, al-ibtidā' (creation, beginning, basis), al-ikhtirā' (to create something that has never existed before) ${ }^{11}$, and al-khalq (creation). ${ }^{12}$

Islam is the true religion because Islam is a religion that follows human nature. Islam is per the human need for obedience to $\operatorname{God}^{13}$, Q.S. The fitrâh religion can guide people in the right way to worship (Q.S. al-Rūm:30). Among the verses relating to fitrâh, Surah al-Rum: 30 is a representative verse to be used as material for analysis, where this verse is the only verse that contains the word fațara and in its masdar isim form, namely fitrâh. ${ }^{14}$

The word fitrâh is associated with the hanif religion at the beginning of the verse, which means it tends to the religion of Allah, which is an attitude that follows human nature. Here it is also linked that religion, namely and religion, is a basic human tendency-likewise, belief in God Almighty. Meanwhile, at the end of the verse, it is stated that the religion is qayyim which means Islam. ${ }^{15}$

Based on the description above, it can conclude that Islam is a religion of fitrâh, namely a religion designed by Allah following the nature of the origin of human events (fitrâh). Dawam Raharjo (2002) ${ }^{16}$ explains that fitrâh can be interprete in two ways; First, Islam, which has a core of acknowledgement and

\footnotetext{
${ }^{9}$ Baharuddin, Aktualisasi Psikologi Islami.......... 14

10 Al-Raghīb al-Așfahānī, Mufradāt Alfāẓ al-Qur'ān..., 640., see Jamāl al-Dīn Muḥammad ibn Mukarram ibn Manzūur, Lisān al-'Arab..., 261 and Murtadha Muthahhari, al-Fițrah..., 8.

11 Jārullah Maḥmūd bin 'Umar al-Zamakhsyari, al-Fā'iq fí Garīb al-Hadì̇, jil. III, (ttp: 'Īsa al-Bābī alHalbī, tt), 127.

${ }^{12}$ Abd al-Raḥman al-Khalīl bin Aḥmad al- Farāhidī, Kitāb al-'Ain, (ttp: tp, tt), hlm. VII/418. Lihat juga M. Quraisy Shihab, Wawasan Al-Quran, Tafsīr Maudlui atas Pelbagai Persoalan Ummat. (Bandung: Mizan, 1996), 283.

13 al-Qur'an dan Tafsirnya Kemenag RI.......... Jilid VII, 496.

14 al-Qur'ān dan Tafsīrnya Kemenag RI, (Jakarta: Lentera Abadi, 2010), Jilid vii, hlm. 495.

15 Dawam Raharjo, Ensiklopedi al-Qur'ān: Tafsīr Sosial Berdasarkan Konsep-Konsep Kunci, (Jakarta: Paramadina, 2002), hlm. 40 dan 117.

16 Dawam Raharjo, Ensiklopedi al-Qur'ān..., hlm. 118.
} 
attitude of submission and submission to Allah, is in line with human tendencies especially the tendency to seek God. Second, Islam created per the nature of events or human nature that Allah glorifies.

According to Fazlur Rahman in Raharjo (2002), the primordial pledge theory can explain the first thing based on his analysis of Q.S al-A'raf/7:172 above. Humans do not realize this primordial pledge. ${ }^{17}$ Yasien Mohamed calls original purity or authentic faith as genuine holiness and genuine human belief. Humans ' universal tendency will also be seen, who always get whispers from their "conscience". The task of the prophets, according to him, is to guard the conscience of man so that he can read what has been inscribed on his heart more clearly and more convincingly. ${ }^{18}$

Humans have brought the essential potential of their existence to Islam. It is different with Judaism, Christianity, and Magian, where humans from birth do not carry the potential to be like that, so their parents have to shape them. That is why -perhaps- in the narration, it is not stated that parents have a role in making their children Muslim.

The description of positive thinking in which all children are born in a state of firah is innate virtue, and such social areas cause people to deviate from this state. Human nature has more than mere knowledge of God inherent in it, but also a love for Him and a willingness to practice religious teachings as a true hanif sincerely. With characters such as Ibn Taimiyyah, Ibn Qayyim al-Jauziyah, Muhammad Ali al-Shobuni, Mufti Muhammad Syafi'ì, Ismail Raji al-Fāruqi, Mohamad Asad, and Shah Waliyullah. Fitrâh also means the hidden power in humans, which has carry since birth; and wants to be a driving force for his personality. With fitrâh, humans tend to divinity and introduce God in all forms of action in their lives. ${ }^{19}$

\section{B. IMPLICATIONS FITRÂH WITH CHILDREN'S EDUCATION}

1. Directing Children to Muslim Personality

The concept of fitrâh believes that the direction of movement of human life dominates by piety and fujur. The definition of fitrâh following the current reality, that the value of actualizing the function of fitrâh is in line with the goals of education and educational epistemology, namely realizing students

17 Dawam Raharjo, Ensiklopedi al-Qur'ān..., 118.

18 Yasien Mohamed, 'Fițrah and Its Bearing on the Principles of Psychology', American Journal of Islamic Social Science, Vol 2, No. 1, 1995, 2.

19 Wahidin, Sains dan Agama..., 21. 
who have the potential for Muslim personalities who oriented towards the actualization of the concept of human nature. ${ }^{20}$

Process of civilizing, inheriting, developing the two sources of Islam in the history of Muslims achieving happiness and goodness. ${ }^{21}$ Based on the interpretation of Q.S. Ar-Rum verse 30.

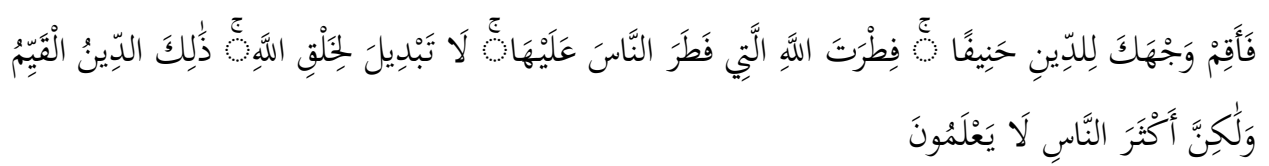

So set thy purpose (O Muhammad) for religion as a man by nature upright - the nature (framed) of Allah, in which He hath created man. There is no altering (the laws of) Allah's creation. That is the right religion, but most men know not -

Based on the verses and hadith above, the child has brought religious nature and then depends on his educators in developing the nature itself according to the child's age in his growth.

Rahardjo (2002) ${ }^{22}$ reveals that the original or basic human tendency is to worship the One God. When humans search for the meaning of life, the human tendency is to find God Almighty. They can find God, although perhaps their environment can turn their eyes on other than God. Nevertheless, even so, fitrâh tends to return to God as an essential manifestation of the tendency to the truth.

2. Instilling a Religious Life View in Students

Shihab (2007) ${ }^{23}$ asserts that the protection of children in the realm of religion has the consequence of having religious education for children at home and at school, following the religion of their parents. To maintain and protect the nature of human beings. Psychologically children have not been able to make choices, especially to understand crucial and complicated issues, namely choosing a religion. ${ }^{24}$

20 Dja'far Siddik, "Menelusuri Konsep Proses Pembelajaran dalam Sistem Pendidikan Islam" dalam Hasan Asari, Amroeni Drajat, (ed), Antologi Kajian Islam, (Bandung: Citapustaka Media, 2004), 176. Also see George R. Knight, 1982, Issues and Alternatives in Educational Philosophy, Michigan: Andrew University Press dalam http://eduartikel.com/aliran-filsafat-pendidikan.

21 Mohammad Muchlis Solichin, Fițrah; Konsep dan Pengembangannya, Tadrîs. Volume 2. Nomor 2. 2007, 246.

22 M. Dawam Rahardjo, Ensiklopedi Al-Qur'ān..., 40.

23 M. Quraish Shihab, Secercah Cahaya Ilahi, (Bandung: PT Mizan Pustaka, 2007), 110. With regard to children's rights to religious education, see Baharuddin, Aktualisasi Psikologi Islami, (Yogyakarta: Pustaka Pelajar, 2005), 145.

${ }^{24}$ M. Quraish Shihab, Secercah Cahaya Ilahi, (Jakarta: PT Mizan Pustaka, 2007), 100.

Al-Manar : Jurnal Komunikasi dan Pendidikan Islam - Volume 10, Nomor 2, Desember 2021 
The role of parents is to instil a religious view of life in their students. The religion of students to be adopted solely depends on the influence of their parents and the natural surroundings. The basics of religious education must have been instilling since the students were still young because otherwise, they may experience difficulties later in achieving the goals of Islamic education given in adulthood. The Qur'an provides an illustration of how Luqman as a parent has instilled religious education in his children as mentioned in Q.S. Luqman (31): 13:

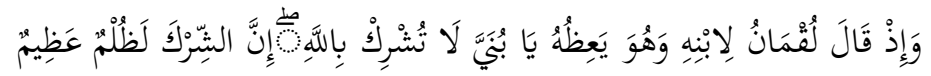

And (remember) when Luqman said unto his son, when he was exhorting him: 0 my dear son! Ascribe no partners unto Allah. Lo! to ascribe partners (unto Him) is a tremendous wrong -

Islamic education is to implant in adulthood or puberty, namely a period of growth experiencing significant changes to the physical and psychological. Zakiah Daradjat (1996) reveals that the adjustment of religious feelings begins from the meeting of mother and father, which produces a fetus in the womb which begins with a prayer to Allah, so that the fetus, when it is born and grows up, becomes a pious child. ${ }^{25}$

History has proven that education that does not pay less attention to faith education will produce graduates who are not good in character. Low morals will be very dangerous for ordinary life, which can destroy the joints of the life of the nation and state. School graduates who lack strong faith will find it very difficult to face life in an increasingly challenging era in the future. ${ }^{26}$

\section{CONCLUSION}

The essence of fitrâh, when associated with Islamic education, is very religious, which emphasizes the approach of faith. Every human being carries a potential called the potential for faith in Allah or the language of his religion monotheism. God created humans with a religious instinct, namely the religion of monotheism. Therefore, humans who do not believe in monotheism are a deviation from their nature.

Humans need a religion that bases on confession and behaviour of submission and submission to God. With religion, humans want to live meaningfully. Religion acts as a human moral control. Religion tells humans always to be awake and able to

25 Zakiyah Daradjat, Ilmu Pendidikan Islam, (Jakarta: Bumi Aksara,1996), hlm. 64. Also see Zuhairini, dkk., Filsafat Pendidikan Islam, (Jakarta: Bumi Aksara,2004), 172.

26 Moh. Solikodin Djaelani, Peran Pendidikan Agama Islam dalam Keluarga dan Masyarakat, Uurnal Ilmiah WIDYA, Juli-Agustus 2013), Vol.1, No. 2, hlm. 101. 
understand themselves. The true religion is Islam, with the alibi of Islam being a religion that is compatible with human nature. Islam is a religion that is fitrâh because it fits the human need to submit to God and guide humans to the correct method of worship (Q. S al-Rum: 30).

Adaptation to the educational environment means that the environment is one of the factors that help determine a student's educational style. Its relevance relates to educational institutions such as the home, the foremost institution where students receive education and guidance from parents and other families. In the family, this is where the student's personality lies.

Schools are critical educational institutions after the family that provide education and teach children about what parents cannot or do not have the opportunity to provide education and teaching in the family. Society is the third educational institution after family and school. Education in society provides openness to influences from the outside world and developments from within students to direct their basic abilities (fitrâh). Education naturally fosters the potential to become citizens of faith, religion, noble character, healthy, knowledgeable, capable, creative, independent, and responsible.

Islam as a religion of nature is not only per human religious instincts but also supports the growth and development of nature to lead to personal integrity and perfection. On the other hand, Islam as a way of life (view of life) based on religious values, contains absolute truths that are transcendental, universal and eternal, so that in faith it is believed by its adherents that it will always be following human nature, meaning that it fulfils human needs. Humans anytime and anywhere (likulli zamanin wa makanin).

\section{REFERENCES}

Achmadi. 2008. Ideologi Pendidikan Islam-Paradigma Humanisme Teosentris. Yogyakarta: Pustaka Pelajar.

Anis, Muh. 2012. Tafsir Ayat-ayat Pendidikan. Yogyakarta: Mentari Pustaka.

Asfahani, (al) Abu al-Qasim al-Husain Ibn Muhammad al-Raghib. tt. Mu'jam alMufradat Li Alfāz al-Qur'ān al-Karīm. Beirut: Dar al-Fikr.

Baharuddin. 2011. Aktualisasi Psikologi Islami, cet. ke-2. Yogyakarta: Pustaka Pelajar.

Boz, Tuba. 2011. Religious Conversion, Models and Paradigms, Epiphany: Journal of Transdisciplinary Studies.

Bukhāri, (al) Muhammad bin Ismā’il Abu Abdillāh. 1422 H. Ṣaḥ̄h Bukhārī. Dār Thuq alNajāh. Jilid 2.

Departemen Agama RI. 2010. al-Qur'an dan Tafsirnya Kemenag RI. Jakarta: Lentera Abadi, Jilid vii. 
Dewan Redaksi Ensiklopedi Islam. 2003. Ensiklopedi Islam Jilid II. Jakarta: Icthtiar Baru van Hoeve.

Djaelani, Moh. Solikodin. 2013. Peran Pendidikan Agama Islam dalam Keluarga dan Masyarakat. Jurnal Ilmiah Widya. Vol.1, No. 2 Juli-Agustus.

Farahidi, (al) Abd al-Raḥman al-Khalīl bin Aḥmad. tt. Kitāb al-'Ain, tp: tp.

Ibnu Mandzur, Jamal al-Din Muhammad ibn Mukarram. 1992. Lisân al-'Arab, Jilid III. Beirut: Dar al-Sadr.

Ilyas, Yunahar. 2006. Tipologi Manusia dalam Al-Qur'an. Yogyakarta: Lambda Press.

Jalaluddin dan Ramayulis.1987. Pengantar Ilmu Jiwa Agama. Jakarta: Kalam Mulia.

Kemenag RI. 2010. al-Qur'ān dan Tafsīrnya (edisi yang disempurnakan). Jaklarta: Lentera Abadi.

Knight, George R. 1982, Issues and Alternatives in Educational Philosophy, Michigan: Andrew University Press dalam http://eduartikel.com/aliran-filsafatpendidikan.

Mohamed, Yasien. 1995. 'Fitrâh and Its Bearing on the Principles of Psychology', American Journal of Islamic Social Science, Vol 2, No. 1

Mujahid. 2005. Konsep Fitrâh dalam Islam dan Impilkasinya terhadap Pendidikan Islam. Jurnal Pendidikan Islam, vol. 2, No. 1.

Muslim bin al-Hajjaj Abu al-Hasan al-Qusyairī al-Naisaburī. T.t. Șahīh Muslim. Jilid 4. Beirut: Dār al-Ihyā' al-Turāṡ al-Islāmī.

Naharin, Sri. 2013. Memaknai Fitrâh Manusia: Satu Interaksi Hadis dengan al-Qur'an. Jurnal Islamic review. Vol. II., No. 3.

Raharjo, Dawam. 2002. Ensiklopedi al-Qur'an: Tafsir Sosial Berdasarkan Konsep-Konsep Kunci. Jakarta: Paramadina.

Shihab, M. Quraish. 2007. Secercah Cahaya Ilahi. Bandung: PT Mizan Pustaka.

Siddik, Dja'far. 2004. “Menelusuri Konsep Proses Pembelajaran dalam Sistem Pendidikan Islam" dalam Hasan Asari, Amroeni Drajat, (ed), Antologi Kajian Islam. Bandung: Citapustaka Media.

Solichin, Mohammad Muchlis. 2007. Fitrâh; Konsep dan Pengembangannya, Tadrîs. Volume 2. Nomor 2.

Wahidin. 2015. Sains dan Agama. Yogyakarta: Penerbit Ombak.

Zamakhsyari, (al) Jārullah Maḥmūd bin 'Umar. tt. al-Fā’iq fï Gharīb al-Hadīś, jil. III, ttp: 'İsa al-Bābī al-Halbī.

Zuhairini, dkk. 2004. Filsafat Pendidikan Islam. Jakarta: PT. Bumi Aksara. 